\title{
ANALYSIS OF THE USE OF INDUSTRIAL CROSSBREEDING TO IMPROVE THE PROFITABILITY OF THE PIG INDUSTRY
}

\author{
Mikhail Bashchenko ${ }^{1} \bowtie$ \\ bioresurs.ck@ukr.net \\ Alexander Boyko \\ Alexander Vaschenko ${ }^{T}$ \\ ${ }^{1}$ Cherkassy Experimental Station of Bioresources of National Academy of Agrarian Sciences of Ukraine \\ 76 Pasterovskaya str., Cherkasy, Ukraine, 18036
}

$\triangle$ Corresponding author

\section{Abstract}

The aim of the research was to conduct an economic assessment of the use of industrial crossbreeding in the pig industry.

The study was carried out in LLC "Mayak-Agro" (Ukraine) and in the laboratories of the Cherkasy National University named after Bohdan Khmelnitsky and the Cherkasy Experimental Station of Bioresources of the National Academy of Sciences of Ukraine. Ukrainian breeds of pigs were used: (Ukrainian BigWhite-1 (UBW-1), Red White-Belt (RWB) and Duroc of the Ukrainian selection "Steppe" (DUSS)). Breeds of English origin: (Big White (EBW), Landrace (L), Pietrain (P)). Crossbreeds, obtained by crossing the breeds, mentioned above. A comprehensive assessment of the reproductive capacity of a sow was carried out taking into account multiple births, the number of piglets at one month of age and the average daily gain during this period. Growth and development were monitored in terms of changes in live weight by individual weighing at birth and every month to a live weight of $100 \mathrm{and} 120 \mathrm{~kg}$.

Regardless of maternal form, in the groups where boars of the breeds Red White-Belt and Pietrain were used, higher indicators of comprehensive assessment of reproductive capacity were obtained. The best fattening qualities characterized piglets, obtained from a combination of sows $(1 / 2 \mathrm{UBW}-1+1 / 2 \mathrm{~L})$ with boars of the Pietrain breed (P). In comparison with other variants of crosses, in this group the animals reached a live weight of $100 \mathrm{~kg} 7.6$ days earlier. Their feed costs per $1 \mathrm{~kg}$ of live weight gain were 3.33 feed units, which corresponds to the expected figure of 3.34 feed units when fattening up to $100 \mathrm{~kg}$ in 170 days. In terms of industrial pork production, breeding of animals of the group $(1 / 4 \mathrm{UBW}-1+1 / 4 \mathrm{~L}+1 / 2 \mathrm{P})$ was more profitable, in which the highest level of profitability was obtained $-22.3 \%$ for fattening up to $100 \mathrm{~kg}$ and $12.5 \%$ for fattening up to $120 \mathrm{~kg}$. Cultivation of three-breed hybrids to a live weight of over $100 \mathrm{~kg}$ led to a decrease in profitability among all research groups. The use of the genotype $1 / 4 \mathrm{UBW}-1+1 / 4 \mathrm{~L}+1 / 2 \mathrm{P}$ in industrial production makes it possible to obtain animals of various weight conditions without significant additional costs and profitability level reduction.

In the course of the research, it was found, that the best option for three-breed crossing is the use of boars of the Pietrain and Red White-Belt breeds. The use of boars of these breeds is ideal for producers looking for bacon pork. The use of boars of the Duroc breed of the Ukrainian selection "Steppe" (DUSS) makes it possible to obtain fatty pork with the possibility of fattening to different weight categories.

Keywords: industrial crossbreeding, Landrace, Pietrain, Ukrainian Big White, Duroc, profitability of pig breeding.

DOI: $10.21303 / 2504-5695.2021 .001954$

\section{Introduction}

Consumer demand for lean pork directs the efforts of scientists to create pigs with intensive growth at an early age, when there is no fat deposition $[1,2]$. The presence of a significant number of breeds of pigs in Ukraine, currently 12, has led to their division in terms of productivity into 3 groups: universal, meat and fat, although it is very conditional, as well as the use of maternal and paternal forms with high lean meat content [3].

EU countries use the "SEUROP" system - payment for sale of pigs not from live weight, but from the actual output of meat from the carcass, taking into account its weight in the steamed condition after slaughter. This approach is recorded in a number of regulations $[4,5]$ : 
- EU Directive No. 3220/84 of 13 November 1984 "On determination of the scale for grading pig carcases;

- EU Directive No. $2967 / 858$ of 24 October 1985 “On establishment of detailed rules for the implementation of the scale for grading pig carcases.

Based on these documents, all EU countries have adapted these requirements to their legislation in different years and implemented this approach. The desire of meat-packing plants to receive carcasses with a high content of lean meat for processing was legally fixed [6, 7$]$. However, in Ukraine there is a completely different system of incentives for pork producers, which provides for a "rough" gradation of carcasses by class, but not on the basis of meat output from a carcass, but by the thickness of lard and some other criteria $[8,9]$.

Farms that have invested in improving the gene pool and optimizing feed supply are in fact short of certain financial resources [10]. According to the Institute of Pig Breeding named after O.V. Kvasnytsky of the National Academy of Agrarian Sciences of Ukraine, most pigs in Ukraine are classified as class $\mathrm{R}$ (45\% of lean meat) and O (40\% of lean meat) according to the European classification, which is certainly far from the wishes of processors. After all, with the same cost of processing one carcass on the conveyor of the meat plant, the profit from the sale of fatty carcasses is much lower [11, 12]. Based on the above, it is important to determine the effectiveness of industrial crossbreeding to increase the profitability of the pig industry.

The aim of the research was to conduct an economic assessment of the use of industrial crossbreeding in the pig industry.

\section{Research materials and methods}

Scientific and economic experiments were conducted during 2015-2017 in the conditions of LLC "Mayak-Agro" (Ukraine) and in the laboratories of Cherkasy National University named after Bohdan Khmelnytsky and Cherkasy Research Station of Bioresources of the National Academy of Agrarian Sciences of Ukraine using:

- Ukrainian breeds (Ukrainian Big White (UBW-1), Red White-Belt (RWB) and Duroc of the Ukrainian selection "Steppe" (DUSS));

- Big White of English origin (EBW), Landrace (L), Pietrain (P));

- crossbreeds obtained by crossing.

The comprehensive assessment of the sow's reproductive capacity was performed taking into account the fertility, the number of piglets at one month of age and the average daily gain for this period.

The evaluation of maternal qualities of sows was calculated on the basis of evaluation index of maternal qualities according to the method of Lash-Moln in the modification of M. D. Berezovsky [13]:

$$
I=B+2 \cdot W+35 \cdot G
$$

where $I$ - maternal quality index; $B$ - number of piglets, heads; $W$ - number of piglets at weaning, heads; $G$ - average daily gain before weaning, g; 2, 35 - evaluation coefficients.

Selection index of reproductive qualities of sows (SIRQS) according to the method of O. M. Tserenyuk [9]:

$$
\mathrm{SIRQS}=6 \cdot X_{1}+9.34 \cdot\left(\frac{X_{2}}{X_{3}}\right)
$$

where SIRQS - Selection index of reproductive qualities of sows; $X_{1}$ - number of piglets, heads; $X_{2}$ - nest weight at weaning, kg; $X_{3}$ - weaning term, days; 6 and 9.34 - coefficients.

Growth was monitored by changes in live weight by individual weighing at birth and each month until a live weight of 100 and $120 \mathrm{~kg}$ [8]. 
All experiments were performed in accordance with Directive No. 2010/63/EU on the protection of animals, used for scientific purposes and in accordance with the recommendations «ARRIVE guidelines (Animal Research: Reporting of In Vivo Experiments)». [14, 15]

The biometric analysis of data was performed by the method of variation statistics of N. A. Plokhinsky on a personal computer using MS Excel. The value of the product and the cost are calculated taking into account the cost of 1 feed unit. The selling price as of January 1, 2021, according to processing companies, is $\$ 1.58$ for $1 \mathrm{~kg}$ of live weight.

\section{Research results and discussion}

An important element that ensures the efficient operation of the pig industry with the production of profitable products is the reproduction of pigs. Given the impact of boars on the overall productivity of the herd, it is important to strictly adhere to the high requirements during their evaluation and selection: boars of three breeds were selected:

1) Duroc of the Ukrainian selection "Steppe";

2) Red White-Belt;

3) Pietrain of English selection.

At the first stage of the research, the expediency of combining sows of the breed Ukrainian Big White (UBW-1) with boars of the breed Landrace (L) was proved to obtain crossbreed sows, which are characterized by a strong type of constitution, high reproductive and maternal qualities. At weaning at 60 days of age, the combination animals (UBW-1 $\times \mathrm{L}),(\mathrm{L} \times \mathrm{UBW}-1)$ and $(\mathrm{EBW} \times \mathrm{L})$ had a live weight of $23.3 \pm 0.42$ to $24.3 \pm 0.48 \mathrm{~kg}$. At the age of three months only in the group (UBW-1 $\times \mathrm{L})$ live weight of piglets was almost $38 \mathrm{~kg}$.

According to the indicators of the evaluation index (Table 1), a probable advantage was obtained from the sows (1/2UBW-1+1/2L) as 42.3-46.5 points. Sows of modern genotypes of the Big White breed of Ukrainian selection in combination with the breeds of Landrace, Red White-belt and Pietrain have a fairly high level of reproductive qualities. This allows the use of these genotypes in crossbreeding systems as maternal and intermediate paternal forms.

Table 1

The complex assessment of the sows' reproductive capacity at the second stage of research, $(M \pm m)$

\begin{tabular}{|c|c|c|c|c|c|c|c|c|}
\hline \multirow{2}{*}{ Parameter } & \multicolumn{8}{|c|}{ Combination } \\
\hline & $\mathbf{I}$ & II & III & IV & $\mathbf{V}$ & VI & VII & VIII \\
\hline Evaluation index, points & $42.2 \pm 1.25$ & $42.3 \pm 1.82$ & $44.9 \pm 1,942$ & $46.5 \pm 2.04$ & $41.7 \pm 1.44$ & $43.0 \pm 1.92$ & $43.8 \pm 1.56$ & $44.6 \pm 1.15$ \\
\hline SIRQS, points & $97.6 \pm 3.48$ & $98.6 \pm 3.06$ & $107.8 \pm 4.75$ & $112.4 \pm 2.96$ & $95.4 \pm 4.41$ & $100.4 \pm 3.01$ & $103.5 \pm 2.86$ & $107.1 \pm 5.80$ \\
\hline
\end{tabular}

Differences in the reproductive capacity of sows depended on the breed of boar. It should be noted, that regardless of maternal form, in the groups where boars of the Red White-belt and Pietrain breeds were used, the highest indicators of the comprehensive assessment of reproductive capacity were obtained. According to the results of the index assessment of reproductive qualities of sows (SIRQS) it was found, that crossing $(1 / 2 \mathrm{UBW}-1+1 / 2 \mathrm{~L} \times \mathrm{P})$ received the highest value $-112.4 \pm 2.96$ points, which is $4.6-13.8$ points higher compared to other crossbreeding options. The rather high level of influence of the genotype of pigs of the original breeds on the reproductive qualities of sows gives grounds to assert the effectiveness of the use of boars of Red White-belt and Pietrain breeds in the process of combination with sows $(1 / 2 \mathrm{UBW}-1+1 / 2 \mathrm{~L})$ at the final stage.

During the period of fattening to a live weight of $100 \mathrm{~kg}$, gross gains at the level of 36.1$41.3 \mathrm{~kg}$ were obtained from crossbreed pigs. This indicator, to some extent, depended on the live weight of piglets at four months of fattening and on the intensity of growth of crossbreed young in the periods before weaning and rearing. On average, $38.9 \mathrm{~kg}$ of gross gain was obtained by groups for the period of 44.4-54.3 days or at the age of 164.4-174.3 days. During this period, probably 
higher gains were obtained from piglets when combining parent pairs $(1 / 2 \mathrm{EBW}+1 / 2 \mathrm{~L} \times \mathrm{DUSS})$ and $(1 / 2 \mathrm{UBW}-1+1 / 2 \mathrm{~L} \times \mathrm{P})-799-813 \mathrm{~g} \mathrm{P}>0,999$, in term - 164.4-171.7 days, respectively (Table 2).

Table 2

The indicators of the results of fattening pigs to a live weight of $100 \mathrm{~kg}$, ( $\mathrm{M} \pm m, n=160$ heads)

\begin{tabular}{cccccc}
\hline Combination & $\begin{array}{c}\text { Live weight in } \\
\text { four month, kg }\end{array}$ & Gross gain, kg & $\begin{array}{c}\text { Age of 100 kg live } \\
\text { weight, days }\end{array}$ & $\begin{array}{c}\text { Average daily } \\
\text { gain, g }\end{array}$ & $\begin{array}{c}\text { Feed cost for 1 kg } \\
\text { gain, feed units }\end{array}$ \\
\hline UBW-1×UBW-1 & $57.5 \pm 1.89$ & $42.5 \pm 1.74$ & $187.5 \pm 1.89$ & $630 \pm 10.3$ & $4.15 \pm 0.072$ \\
$1 / 2 \mathrm{UBW}-1+1 / 2 \mathrm{~L} \times \mathrm{DUSS}$ & $59.1 \pm 1.73$ & $40.9 \pm 1.74$ & $174.3^{* * *} \pm 1.17$ & $753^{* * *} \pm 16.9$ & $3.68 \pm 0.085$ \\
$1 / 2 \mathrm{UBW}-1+1 / 2 \mathrm{~L} \times \mathrm{RWB}$ & $61.2 \pm 1.96$ & $38.8 \pm 2.01$ & $169.9^{* *} \pm 5.10$ & $778^{* * *} \pm 11.4$ & $3.51 \pm 0.066$ \\
$1 / 2 \mathrm{UBW}-1+1 / 2 \mathrm{~L} \times \mathrm{P}$ & $63.9^{*} \pm 2.08$ & $36.1 \pm 2.11$ & $164.4^{* * *} \pm 0.75$ & $813^{* * *} \pm 10.3$ & $3.33 \pm 0.069$ \\
EBW $\times \mathrm{EBW}$ & $57.1 \pm 2.12$ & $42.9 \pm 1.32$ & $182.6 \pm 2.12$ & $685 \pm 14.9$ & $3.97 \pm 0.080$ \\
$1 / 2 \mathrm{EBW}+1 / 2 \mathrm{~L} \times \mathrm{DUSS}$ & $58.7 \pm 1.50$ & $41.3 \pm 2.18$ & $171.7^{* * *} \pm 1.79$ & $799^{* * *} \pm 19.1$ & $3.59^{* *} \pm 0.093$ \\
$1 / 2 \mathrm{EBW}+1 / 2 \mathrm{~L} \times \mathrm{RWB}$ & $60.7 \pm 1.64$ & $36.9 \pm 1.83$ & $174.1^{*} \pm 4.36$ & $726^{*} \pm 14.8$ & $3.67^{* *} \pm 0.035$ \\
$1 / 2 \mathrm{EBW}+1 / 2 \mathrm{~L} \times \mathrm{P}$ & $62.9 \pm 1.87$ & $37.1 \pm 1.88$ & $169.6^{* * *} \pm 1.74$ & $748^{* *} \pm 16.3$ & $3.51^{* * *} \pm 0.048$
\end{tabular}

Notes: * $-P>0.95 ; * *-P>0.99 ; * * *-P>0,999$ in comparison with a combination of purebred animals of the appropriate genotypes

The pigs received from a combination of sows $(1 / 2 \mathrm{UBW}-1+1 / 2 \mathrm{~L})$ with boars of the Pietrain breed $(\mathrm{P})$ were characterized by the best fattening qualities. Compared with other variants of crosses, in this group the animals reached a live weight of $100 \mathrm{~kg} 7.6$ days earlier. The cost of feed per $1 \mathrm{~kg}$ of live weight gain amounted to 3.33 feed units, which corresponds to the expected rate of 3.34 feed units when fattening up to $100 \mathrm{~kg}$ in 170 days.

The cost-effectiveness of using pigs of meat genotypes in crossbreeding depends on many factors, including fattening and reproductive qualities. The results of the evaluation of two-breed and pure-bred pigs, according to these indicators, indicate certain differences, which depend on the methods and conditions of breeding, and the original parental genotypes. For the entire period of the research and evaluation of the economic efficiency of the cost of keeping, fattening, conditions for pigs of different breeds did not change, and therefore, the influence of paratypic factors was leveled (Table 3). The main criteria that determined the profitability of the industry, in this case, were the cost of feed and the duration of animals fattening. The yield of additional products is directly dependent on live weight gain, especially in the period up to $100 \mathrm{~kg}$.

Table 3

The economic efficiency from the sale of crossbreed young animals

\begin{tabular}{|c|c|c|c|c|c|c|}
\hline \multirow{2}{*}{ Parameter } & \multicolumn{6}{|c|}{ Combination } \\
\hline & I & II & III & IV & $\mathbf{V}$ & VI \\
\hline \multicolumn{7}{|c|}{ Fattening up to $100 \mathrm{~kg}^{1}$} \\
\hline Age of live weight, days & 174.3 & 169.9 & 164.4 & 171.7 & 174.1 & 169.6 \\
\hline Average daily gain, $\mathrm{g}$ & 753 & 778 & 813 & 799 & 726 & 748 \\
\hline Feed costs for $1 \mathrm{~kg}$ gain, feed units & 3.68 & 3.51 & 3.33 & 3.59 & 3.67 & 3.51 \\
\hline Cost of $1 \mathrm{~kg}$ gain, US dollars & 1.43 & 1.35 & 1.29 & 1.40 & 1.43 & 1.37 \\
\hline Profit from realization of $1 \mathrm{~kg}$ of live weights US dollars & 0.15 & 0.22 & 0.29 & 0.19 & 0.16 & 0.22 \\
\hline Profitability level, $\%$ & 10.5 & 16.3 & 22.5 & 13.6 & 11.2 & 16.1 \\
\hline \multicolumn{7}{|c|}{ Fattening up to $120 \mathrm{~kg}^{1}$} \\
\hline Age of live weight, days & 199.7 & 194.2 & 186.9 & 196.6 & 199.6 & 194.3 \\
\hline Average daily gain, $\mathrm{g}$ & 789 & 825 & 887 & 802 & 786 & 811 \\
\hline Feed costs for $1 \mathrm{~kg}$ gain, feed units & 4.02 & 3.83 & 3.62 & 3.92 & 4.00 & 3.84 \\
\hline Cost of $1 \mathrm{~kg}$ gain, US dollars & 1.56 & 1.49 & 1.41 & 1.52 & 1.56 & 1.49 \\
\hline Profit from realization of $1 \mathrm{~kg}$ of live weights US dollars & 0.02 & 0.10 & 0.18 & 0.06 & 0.03 & 0.09 \\
\hline Profitability level, $\%$ & 1.3 & 6.7 & 12.8 & 3.9 & 1.9 & 6.1 \\
\hline
\end{tabular}

Notes: ${ }^{1}$ The selling price of $1 \mathrm{~kg}$ of live weight is 1.58 US dollars; $I-1 / 4$ UBW-1+1/4L+1/2DUSS; II - 1/4UBW-1+1/4L+1/2RWB; $I I I-1 / 4 U B W-1+1 / 4 L+1 / 2 P ; I V-1 / 4 E B W+1 / 4 L+1 / 2 D U S S ; V-1 / 4 E B W+1 / 4 J+1 / 2 R W B ; V I-1 / 4 E B W+1 / 4 L+1 / 2 P$ 
The effect of complex crossing was not the same and depended on the selection of the original maternal and paternal forms. When fattening crossbreed piglets to a live weight of $100 \mathrm{~kg}$, the most short terms were obtained - 164.4-169.9 days in the selection of pairs $(1 / 2 \mathrm{UBW}-1+1 / 2 \mathrm{~L} \times \mathrm{P}$, $1 / 2 \mathrm{EBW}+1 / 2 \mathrm{~L} \times \mathrm{P}$ and $1 / 2 \mathrm{UBW}-1+1 / 2 \mathrm{~L} \times \mathrm{RWB})$. Accordingly, in these groups the lowest feed costs per $1 \mathrm{~kg}$ of live weight gain were 3.33-3.51 feed units. The worst in terms of these indicators were the mixtures, obtained in the combination (1/2UBW-1+1/2L $\times$ DUSS). Under conditions of industrial pork production breeding of animals of the group $(1 / 4 \mathrm{UBW}-1+1 / 4 \mathrm{~L}+1 / 2 \mathrm{P})$, which obtained the highest level of profitability $-22.5 \%$ for fattening up to $100 \mathrm{~kg}$ and $12.8 \%$ for fattening up to $120 \mathrm{~kg}$, was more profitable. The lowest profitability level of production was obtained when combining sows (UBW-1 $\times \mathrm{L})$ with boars of the Duroc breed of the Ukrainian selection "Steppe" (10.5\% and $1.3 \%$ depending on the fattening period) and sows $(\mathrm{EBW} \times \mathrm{L})$ with boars of the Red White-belt (11.2\% and $1.9 \%$ depending on fattening terms).

The rearing of three-breed crossbreeds to a live weight of more than $100 \mathrm{~kg}$ led to a decrease in profitability among all experimental groups. The maximum decrease in the profitability level was obtained in the group of crossbreeds of genotypes: $1 / 4 \mathrm{UBW}-1+1 / 4 \mathrm{~L}+1 / 2 \mathrm{DUSS}$ in 8.1 times, $1 / 4 \mathrm{EBW}+1 / 4 \mathrm{~L}+1 / 2 \mathrm{RWB}$ in 5.9 times, $1 / 4 \mathrm{EBW}+1 / 4 \mathrm{~L}+1 / 2 \mathrm{DUSS}$ in 3.5 times. Rearing animals of this genotype to a live weight of more than $100 \mathrm{~kg}$ is not appropriate. It leads to overuse of feed, energy resources and finances for keeping and care.

A 1.8-fold decrease in the profitability level was observed when rearing to a live weight of $120 \mathrm{~kg}$ in animals of the genotype $(1 / 4 \mathrm{UBW}-1+1 / 4 \mathrm{~L}+1 / 2 \mathrm{P})$. The use of such mixtures in industrial production makes it possible to obtain animals of different weight conditions without significant additional costs and reduced profitability.

The research took into account a number of limitations: subject (analysis of research relevance, choice of methods and genotypes of breeds for crossing, choice of methods for assessing the obtained genotypes, quantitative (number of piglets, sow's milk yield, survival of piglets, average daily gain, duration of fattening, age of animals, weight category, economic efficiency) and qualitative (animal genotype, morphological composition of carcasses, qualitative composition of pork).

\section{Conclusions}

In the course of research it was found, that the best option for crossing is the use of boars of Pietrain and Red White-belt breeds, in these groups are the lowest feed costs per $1 \mathrm{~kg}$ of live weight gain - 3.33-3.51 feed units, and the shortest possible time to achieve a live weight of $100 \mathrm{~kg}-$ 164.4-169.9 days. It is recommended to use boars of these breeds for producers who want to get bacon pork. The use of boars of the Duroc breed of the Ukrainian selection "Steppe" (DUSS) gives the chance to receive fatty pork with a possibility of fattening to various weight categories.

The study was conducted without personal commercial interest in order to obtain a scientifically sound result, which causes no conflict of interest.

\section{References}

[1] Voytenko, S. L., Sidorenko, E. V., Dzhus, P. P. (2019). Sovremennoe sostoyanie i problemy razvitiya skotovodstva i svinovodstva Ukrainy. Sbornik nauchnykh statey po materialam Mezhdunarodnoy nauchno-prakticheskoy konferentsii. Minsk: Respublikanskoe unitarnoe predpriyatie "Izdatelskiy dom "Belorusskaya nauka", 36-42.

[2] Kolomiiets, S. M. (2011). Suchasnyi stan vyrobnytstva svynyny v Ukraini i za kordonom. Suchasni problemy vdoskonalennia tekhnichnykh system i tekhnolohii u tvarynnytstvi». Visnyk kharkivskoho natsionalnoho tekhnichnoho universytetu silskoho hospodarstva imeni Petra Vasylenka, 108, 9-18.

[3] Balatsky, V., Bankovska, I., Saienko, A. (2016). Association between leptin receptor gene polymorphism and quality of both meat and back fat in large white pigs of ukrainian breeding. Agricultural Science and Practice, 3 (2), 42-48. doi: http://doi.org/ 10.15407/agrisp3.02.042

[4] Christensen, O. F., Nielsen, B., Su, G., Xiang, T., Madsen, P., Ostersen, T. et. al. (2019). A bivariate genomic model with additive, dominance and inbreeding depression effects for sire line and three-way crossbred pigs. Genetics Selection Evolution, 51 (1). doi: http://doi.org/10.1186/s12711-019-0486-2

[5] Gastmann, Ch. (1990). Die Schlachtkorperbewertimg nach SEUROP-Handelsklassen auch in der DDR. Tierzucht, 9, 413-415. 
[6] Bankovska, I. B. (2014). Evaluation of pigsmeat for quality levels. Visnyk Sumskoho natsionalnoho ahrarnoho universytetu, 2 (2 (25)), 148-153.

[7] Tusell, L., Gilbert, H., Riquet, J., Mercat, M.-J., Legarra, A., Larzul, C. (2016). Pedigree and genomic evaluation of pigs using a terminal-cross model. Genetics Selection Evolution, 48 (1). doi: http://doi.org/10.1186/s12711-016-0211-3

[8] Bankovska, I., Oliinychenko, Y., Balatsky, V., Buslyk, T., Hryshchenko, S., Susol, R. (2020). Association of LEP- and CTSF-genotypes with levels of meat quality PSE, NOR and DFD in pigs of large white breed of Ukrainian selection. Agricultural Science and Practice, 7 (1), 14-23. doi: http://doi.org/10.15407/agrisp7.01.014

[9] Pelikh, V., Ushakova, S., Pelikh, N. (2019). Index evaluation of pigs and determination of selection limits. Agricultural Science and Practice, 6 (1), 67-74. doi: http://doi.org/10.15407/agrisp6.01.067

[10] Ibatulin, M., Varchenko, O., Svynous, I., Klymchuk, O., Drahan, O., Herasymenko, I. (2019). Factors of ensuring the competitiveness of Ukraine's pig breeding production in external markets. Agricultural Science and Practice, 6 (2), 29-46. doi: http:// doi.org/10.15407/agrisp6.02.029

[11] Svyni dlia zaboiu. Tekhnichni umovy: DSTU 4718:2007. Kyiv: Derzhspozhyvstandart Ukrainy, 7.

[12] Esfandyari, H., Thekkoot, D., Kemp, R., Plastow, G., Dekkers, J. (2020). Genetic parameters and purebred-crossbred genetic correlations for growth, meat quality, and carcass traits in pigs. Journal of Animal Science, 98 (12). doi: http://doi.org/10.1093/ jas/skaa379

[13] Berezovskyi, M. (2008). Osoblyvosti vitchyznianoi ta zarubizhnoi selektsii z liniinoho rozvedennia svynei. Svynarstvo, 56, $6-10$.

[14] The ARRIVE guidelines 2.0: updated guidelines for reporting animal research. Available at: https://arriveguidelines.org/ arrive-guidelines

[15] Directive 2010/63/EU of the European Parliament and of the Council of 22 September 2010 on the protection of animals used for scientific purposes Text with EEA relevance. Available at: http://data.europa.eu/eli/dir/2010/63/oj

Received date 08.06.2021

(C) The Author(s) 2021

Accepted date 20.07.2021

This is an open access article

Published date 30.07.2021 under the Creative Commons CC BY license

How to cite: Bashchenko, M., Boyko, A., Vaschenko, A. (2021). Analysis of the use of industrial crossbreeding to improve the profitability of the pig industry. EUREKA: Life Sciences, 4, 3-8. doi: https://doi.org/10.21303/2504-5695.2021.001954 